\title{
Literature Review and Clinical Presentation of Cervical Spondylitis Due to Salmonella Enteritidis in Immunocompetent
}

\author{
Zhi-Yun Feng, Fang Guo, Zhong Chen \\ Department of Orthopedics, The First Affiliated Hospital of College of Medicine, Zhejiang University, Hangzhou, China
}

\begin{abstract}
A 48-year-old woman was presented to our clinic with some fever and neck pains for about one month. Based on the symptoms and results of image, an empirical diagnosis of tuberculous cervical spondylitis was made. The pain was not significantly decreased after anti-tuberculosis therapy. And, 3 weeks later, she was re-admitted to our hospital for the unbearable pain. An exploration of the C4/5 by the anterior medial approach was recommended to evaluate the germ and debridement. Bacteriological tests showed that the pathogen was Salmonella Enteritidis. The pain was relieved significantly after operation and sensitive antibiotic treatments. Infections with Salmonella Typhi or Salmonella Paratyphi have been well-documented, while there are few reports of cervical spondylitis caused by Salmone/la Enteritidis. We reported a case of a healthy woman with whom pyogenic cervical spondylitis of Salmonella Enteritidis was corroborated and treated and reviewed according to previous reports about spondylitis caused by Salmonella Enteritidis in the literature.
\end{abstract}

Keywords: Salmonella Enteritidis; Cervical vertebrae; Spondylitis; Immunocompetent

\section{Introduction}

Salmonella Enteritidis (SE) usually resides in the intestines of human beings and animals, and typically causes enteritis. Occasionally, it may affect some extra-intestinal organs such as the brain, thyroid, and musculoskeletal systems for patients with underlying diseases or with factors that suppress host resistances [1]. Infections of SE which involve the spine, particularly the cervical spine in the immunocompetent, is rare. To our knowledge, infections with Salmonella Typhi [2-7] or Salmonella Paratyphi $[3,8]$ have been well documented, but there are few reports on cervical spondylitis caused by SE.

We report a case of a healthy middle-aged woman with whom pyogenic cervical spondylitis of SE was corroborated and treated, and reviewed according to previous reports about spondylitis caused by SE in literature. The present case is unique in that it occurred in an immunocompetent from non-endemic areas without known sources of Salmonella infections and prodromal gastrointestinal disorders. Furthermore, the clinical presentation and image studies are similar to tuberculosis spondylitis, and, thus, are misdiagnosed as tuberculosis spondylitis on the first admittance. Therefore, the purpose of this report is to alert others for the possibilities of SE spondylitis in immunocompetent and to provide recommendations for diagnosis and treatments.

Received Sep 3, 2012; Revised May 31, 2013; Accepted Jun 29, 2013

Corresponding author: Zhong Chen

Department of Orthopedics, The First Affiliated Hospital of College of Medicine, Zhejiang University,

\#79, Qingchun Road, Hangzhou 310003, Zhejiang, China

Tel: +86-571-8723-6128, Fax: +86-571-8723-6628, E-mail: chenzhongzju@gmail.com 


\section{Case Report}

A 48-year-old woman was presented to our clinic with some fever and neck pains for about one month. She had no significant neck injury history. Her neck pains occurred after days of low degree fever and fatigue, with shoulder and arm pains. She rated the neck pain 7 out of 10 points (visual analogue scale). The pain, with dizziness and headaches, increased at night. Although the neck pain involved both shoulders and arms, there were no specific distributions of arm pains. She did not have any numbness in either arms. She felt a low fever everyday but denied a contact with tuberculosis. She walked normally and continued her work at home. She had no bowel and bladder problems.

Physical examinations revealed restricted neck rotations and obvious tenderness on her shoulders. For her neurological examination of the upper limb, no abnormality was found. Spurling signs and Lhermitte's test were not detected. Hoffman's sign and Babinski's sign were negative. Her tandem gait was normal. Her body temperature was $38.2^{\circ} \mathrm{C}$.

The laboratory tests revealed that white blood cell (WBC) was counted as $3.8 \times 10^{9} / \mathrm{L}$, with $57 \%$ neutrophils, and $30.1 \%$ leukocyte. C-reactive protein (CRP) level was $7.29 \mathrm{mg} / \mathrm{L}$ and erythrocyte sedimentation rate (ESR) was $28 \mathrm{~mm} / \mathrm{hr}$. Both purified protein derivative tests and tuberculosis antibody colloidal gold diagnostic tests were negative.

Lateral radiograph revealed a loss of lordosis on the cervical spine by destructions of the fifth cervical vertebrae (C5) and narrowing of the intervertebral disk space between $\mathrm{C} 5$ and the sixth cervical vertebrae (C6). In addition, magnetic resonance imagings (MRIs) of the cervical spine demonstrated uneven compressions of the intervertebral disk spaces between C5 and C6. Endplates and vertebrae were moth-eaten damaged. This was combined with well-defined paraspine and intraspine abnormal signals wrapped with smooth walls, all in parallel with tuberculous spondylitis which is inconsistent with the pyogenic (Fig. 1).

An empirical diagnosis of tuberculosis (TB) cervical spondylitis was made and the patient underwent classic anti-tuberculosis therapy with isoniazid, rifampicin, and ethambutol, and anti-infective treatments with penicillin and gentamicin. Yet, the chemotherapy for TB received no improvements in neck pain after 3 weeks. Repeated lab tests revealed that WBC was $7.2 \times 10^{9} / \mathrm{L}$, with $70 \%$ of neutrophils and $17 \%$ of leukocyte, while CRP was 2.68 $\mathrm{mg} / \mathrm{L}$ and ESR $23 \mathrm{~mm} / \mathrm{hr}$. Based on the limited responses of anti-TB therapy, we realized that TB might not be the pathogen. Therefore, an exploration of the C4/5 through the anterior medial approach was recommended to evaluate the germ and debridement.

In the surgery, hypertrophic and edematous prevertebral fascia was noticed. On the right edge of $\mathrm{C} 5$ vertebral
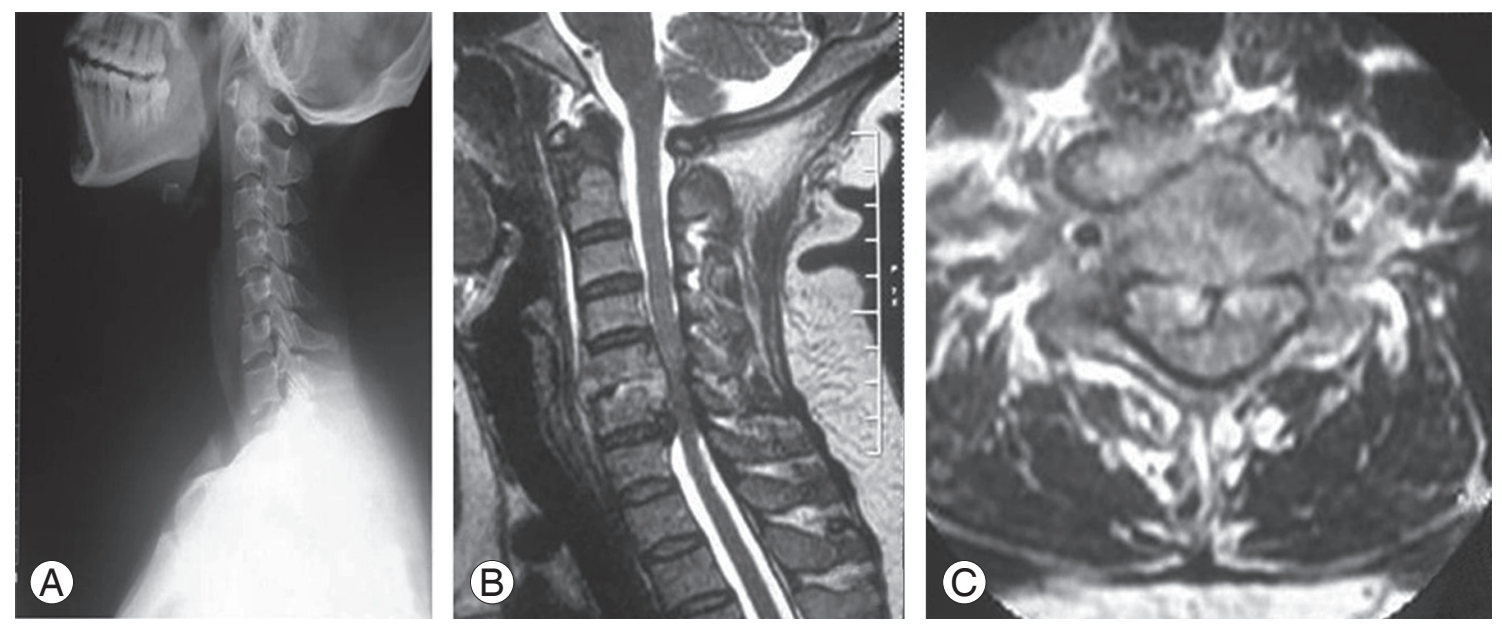

Fig. 1. Radiology studies at admission. (A) Plain radiographic at admission demonstrated it exists narrowing of the intervertebral disk space between C5 and C6. (B) Sagittal T2 weighted image showed uneven compression of the intervertebral disk space between C5 and C6. Endplates and vertebrae were moth-eaten damaged. High signal intensity in endplates of C5 and C6 and paraspinal mass were present. (C) T2 weighted axial image showed well-defined paraspine and intraspine abnormal signals wrapped with smooth wall. 
body, there was an abscess in the size of about $1 \times 1 \times 0.6$ $\mathrm{cm}^{3}$. Needle puncture containing about $1 \mathrm{~mL}$ yellow feculent abscess was sent for culture. The abscess was drained and adjacent inflammatory tissues were removed. The C5/6 disc and its adjacent vertebral endplates were damaged. Scattered local bone destructions and hyperplastic granulations were found in C5 vertebral body. Frozen pathological section examinations of the pre-vertebral tissues revealed infiltration of neutrophils and tissue cells, but no evidences of malignancy and tuberculosis. Acid-fast bacillus test of purulent specimen smear was negative. The $\mathrm{C} 5$ corpectomy was then performed, and C4/5 and C5/6 discs were removed, followed by autoiliac grafts and anterior plate instrumentations (InterTan, Smith \& Nephew, Memphis, TN, USA). Gel foams filled with streptomycin were used to cover the plate and screws.

Histological study revealed chronic infections of C5 vertebra, with apparent neutrophils infiltration and granulation tissues hyperplasia. No evidences of tuberculosis, such as epithelioid cell hyperplasia and langhan's cell, were detected. Instead, bacteriology study showed that the pathogen was SE. She was diagnosed as having cervical spondylitis caused by SE. Based on sensitivity test, levofloxacin was administrated through intravenous injection for 3 weeks, followed by oral antibiotic for another 2 weeks. At 1 month follow-up, her neck pain completely disappeared and radiography showed signs of

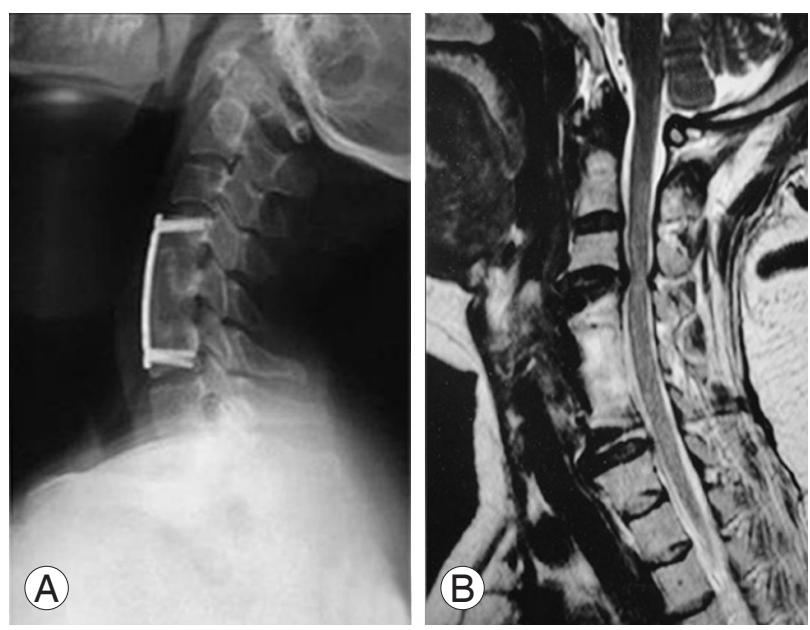

Fig. 2. Radiology studies at follow-up. (A) Plain radiograph postoperative one year confirmed that C5 and C6 have fused together well, no pseudarthrosis or dislocation of screws or plate. (B) Sagittal T2 weighted image demonstrated no relapse of inflammation. bone growth. At 1.5 year of follow-up, C4-6 fusion was obtained. At 5-year of follow-up, she was symptoms-free and magnetic resonance showed a fine fusion from $\mathrm{C} 4$ to C6. However, accelerated degeneration was observed in the adjacent $\mathrm{C} 3 / 4$ discs (Fig. 2).

\section{Discussion}

Pyogenic spondylitis caused by Salmonella Typhi or Salmonella Paratyphi has been well documented. Miller et al. [7] reported two normal patients with spondylitis caused by Salmonella group B (Salmonella Typhi). Amritanand et al. [3] reported his experiences with 11 cases, all of them were Salmonella Typhi or Salmonella Paratyphi. The Salmonella Paratyphi spondylitis of lumbar spine was also being reported in English literature [8]. A cervical spondylitis due to $\mathrm{SE}$ is a rare entity. We reviewed worldwide medical literatures with the use of Medline dating back to 1960 and referenced the retrieved articles. We obtained reports on 5 patients with spondylitis caused by this organism [5,9-11], and the detailed characteristics of these cases and our case are outlined in Table 1.

Pains of back or shoulder and fever occurred in most patients. Of the 6 cases described herein, five were misdiagnosed initially (Table 1). Spondylitis due to SE can be misdiagnosed as neoplastic, Guillain-Barre, atypical borreliosis, atypical pneumonia and scrub typhus, tuberculosis. It may be attributed to the lack of awareness for this organism to be the pathogen of spondylitis or absence of prodomal gastrointestinal disorders. We recommended Widal test to be carried out to verify if any Salmonella infections existed insidiously when the pains or other symptoms were not improved. But aspiration of the abscess may be more helpful to make prompt and defined diagnosis [12].

The first interest point in this case is that Salmonella cervical spondylitis occurred in an immunocompetent without prodomal gastrointestinal disorders. All the other 5 cases in the table except our case have immunodepression factors such as diabetes mellitus, prednisone consumption, chronic renal failure and drinking. A man infected with the SE bacterium often undergoes fever, abdominal cramps, and diarrhea and remote Salmonella infections frequently afflicted patients with immunodepression factors [1]. However, in this case, she had no prodromal gastrointestinal disorders and typhoid fever other than low fever during the night. Based on her med- 
Table 1. Clinical characteristics of the 6 patients with SE spondylitis

\begin{tabular}{|c|c|c|c|c|c|c|c|}
\hline $\begin{array}{l}\text { Age (yr) } \\
\text { /Sex }\end{array}$ & $\begin{array}{l}\text { Associated } \\
\text { condition }\end{array}$ & Site & $\begin{array}{l}\text { Clinical } \\
\text { manifestation }\end{array}$ & $\begin{array}{l}\text { Misdiagnosis; } \\
\text { antimicrobial } \\
\text { regimen }\end{array}$ & $\begin{array}{l}\text { Surgerical } \\
\text { treatment }\end{array}$ & $\begin{array}{l}\text { Outcome/ } \\
\text { follow-up } \\
\text { duration }\end{array}$ & Reference \\
\hline 54/Male & $\begin{array}{l}\text { Gastsroentertis, } \\
\text { generalized weak- } \\
\text { ness, diabetes } \\
\text { mellitus }\end{array}$ & Lumbar & $\begin{array}{l}\text { Fever and chills, } \\
\text { back pain }\end{array}$ & $\begin{array}{l}\text { Ceftriaxione/4 wk; cipro- } \\
\text { floxacin/13 wk }\end{array}$ & $\begin{array}{l}\text { Debridement, two- } \\
\text { stage bone graft, } \\
\text { no internal fixation }\end{array}$ & $\begin{array}{l}\text { Recov- } \\
\text { ered/15 mo }\end{array}$ & [1] \\
\hline 56/Female & $\begin{array}{l}\text { RA, prednisone } \\
\text { taken daily, irritable } \\
\text { bowel syndrome }\end{array}$ & Lumbar & $\begin{array}{l}\text { Febrile, low back } \\
\text { pain }\end{array}$ & $\begin{array}{l}\text { Misdiagnosed as neo- } \\
\text { plastic; ofloxacin iv/4 wk; } \\
\text { ofloxacin oral } / 5.5 \text { wk }\end{array}$ & No & $\begin{array}{l}\text { Recovery } \\
\text { delayed/12 } \\
\text { mo }\end{array}$ & [2] \\
\hline 53/Male & $\begin{array}{l}\text { Diarrhea, heavy } \\
\text { drinker }\end{array}$ & Cervical & $\begin{array}{l}\text { Low fever, pares- } \\
\text { thesia, weakness } \\
\text { of extremities }\end{array}$ & $\begin{array}{l}\text { Misdiagnosed as Guillain- } \\
\text { Barre; cefmetazole, } \\
\text { amikacin/4 wk }\end{array}$ & $\begin{array}{l}\text { Debridement and } \\
\text { one-stage bone } \\
\text { graft }\end{array}$ & Recovery & [3] \\
\hline 19/Male & Meningism & Lumbar & $\begin{array}{l}\text { Lumbar region } \\
\text { pain }\end{array}$ & $\begin{array}{l}\text { Misdiagnosed as atypical } \\
\text { borreliosis; ciprofloxa- } \\
\text { cin/6 wk }\end{array}$ & No & Recovery & [4] \\
\hline 62/Male & $\begin{array}{l}\text { Chronic renal } \\
\text { failure }\end{array}$ & Lumbar & $\begin{array}{l}\text { Back pain, fever, } \\
\text { hypoxia }\end{array}$ & $\begin{array}{l}\text { First misdiagnosed as } \\
\text { atypical pneumonia, then } \\
\text { scrub typhus; ceftriax- } \\
\text { one/4 wk, ciprofloxacin } \\
\text { ceftriaxone/13 wk }\end{array}$ & $\begin{array}{l}\text { Drainage of the } \\
\text { focal }\end{array}$ & $\begin{array}{l}\text { Improve- } \\
\text { ment }\end{array}$ & [5] \\
\hline 48/Female & None & Cervical & $\begin{array}{l}\text { Low fever, shoul- } \\
\text { der pain }\end{array}$ & $\begin{array}{l}\text { Misdiagnosed as tubercu- } \\
\text { losis spondylitis; levoflox- } \\
\text { acin iv/3 wk, levofloxacin } \\
\text { oral/8 wk }\end{array}$ & $\begin{array}{l}\text { Debridement and } \\
\text { one-stage bone } \\
\text { graft with internal } \\
\text { fixation }\end{array}$ & $\begin{array}{l}\text { Recovery } \\
\text { soon/5 yr }\end{array}$ & [6] \\
\hline
\end{tabular}

SE, Salmonella Enteritidis; RA, rheumatoid arthritis.

ical history and laboratory tests at our hospital, she had no apparent immunologic abnormalities. This reminds us to be aware of Salmonella spondylitis in the medical community, even when treating the immunocompetents.

On the other hand, it is easy to be confused with tuberculous spondylitis in clinical and image presentations. Kim et al. [13] compared pyogenic spondylitis with tuberculous spondylitis in associated illnesses clinical, radiological, and laboratory features; they concluded previous invasive spinal procedures, preceding bacteremia, fever, higher WBC, CRP, alkaline phosphatase, and higher fractions of neutrophils are all indications of pyogenic spondylitis. Recent surveys revealed that MRI is the best noninvasive method for assessing the spinal infections and may be a helpful technique for differentiation of tuberculous spondylitis from pyogenic spondylitis. Harada et al. [14] found that well-defined paraspinal abnormal signal, thin and smooth abscess wall, presence of paraspinal or intraspinal abscess, and thoracic spine involvement are suggesting tuberculous spondylitis. However, the key to diagnosis is recovery of the organisms, and Widal test may be helpful. In the present case, the MRI is similar to tuberculous spondylitis with a smooth abscess wall and well-defined paraspinal abnormal signals (Fig. 1). Widal test was not performed due to the rarity of the organism in spondylitis and our lack of awareness for this problem. These factors could be partly proposed to account for misdiagnosis at the first time.

Under the premise of the use of sufficient antibiotics, there is no doubt to have radical debridement for the abscess and infected tissues in cervical, followed by an anterior fusion with autograft, allograft, and titanium cage [15]. However, for the remaining vertebral space after most of the purulent materials have been removed, whether we treat it with one-stage bone grafting and internal fixation, or we perform two-stage operation is controversial. The orthodox view was that one-stage therapy may lead to poor stability, low fusion rates, losses of height of vertebrae and formations of a layer of exo-polysaccharides known as glycocalyx. But recently, Linhardt et al. [16] and Lee et al. [17] have reported that if the purulent materials were completely eliminated and the course of antibiotic therapy was enough, it was safe to carry out an one-stage operation by using internal fixation. Koroves- 
sis et al. [18] held that instrument-combined, one-stage surgery allowed early and long-term results for patients with cervical and lumbar osteomyelitis. Nakase et al. [19] suggested that two-stage management may be suitable for carefully selected patients with severe diabetes mellitus or long-term steroid intakes. Because the large diameter of the cervical spinal cord relative to the spinal canal and the significant range of motions on the cervical spine, the cervical osteomyelitis is a unique entity and a small epidural infection can lead to great pains and neurological deficits [12]. Thus, it should be treated discriminatingly from lumbar or thoracic spondylitis. In the present case occurring at the cervical spine, because the patient had unbearable pain and structure instability radiology, surgical treatment was recommended. Firstly, we removed the infected tissues radically, followed by rinse and dip with iodine. Secondly, autologous bone grafts and titanium board internal fixation were performed, the surface of the plate was filled up with latin sponge, gelation foam dipped with antibiotic (streptomycin). Then methylprednisolone ( $80 \mathrm{mg}$, bid) was used intravenously for 3 days to alleviate the edema.

\section{Conflict of Interest}

No potential conflict of interest relevant to this article was reported.

\section{References}

1. Higgins GA, Sandiford JA, Blair WC. Remote salmonella infections. World J Surg 1982;6:236-40.

2. Laloum E, Zeller V, Graff W, et al. Salmonella typhi osteitis can mimic tuberculosis. A report of three cases. Joint Bone Spine 2005;72:171-4.

3. Amritanand R, Venkatesh K, Sundararaj GD. Salmonella spondylodiscitis in the immunocompetent: our experience with eleven patients. Spine (Phila $\mathrm{Pa}$ 1976) 2010;35:E1317-21.

4. Govender S, Parbhoo AH, Rasool MN, Maharaj J. Salmonella typhi spondylitis. J Pediatr Orthop 1999;19:710-4.

5. Santos EM, Sapico FL. Vertebral osteomyelitis due to salmonellae: report of two cases and review. Clin Infect Dis 1998;27:287-95.

6. Carvell JE, Maclarnon JC. Chronic osteomyelitis of the thoracic spine due to Salmonella typhi: a case re- port. Spine (Phila Pa 1976) 1981;6:527-30.

7. Miller ME, Fogel GR, Dunham WK. Salmonella spondylitis. A review and report of two immunologically normal patients. J Bone Joint Surg Am 1988;70:463-6.

8. Kumar P, Mahmoodi SM, Kalaparambil Moosa N, Edgar M, Samt HA, Hussain RA. Salmonella paratyphi spondylitis: a case report. Eur Spine J 2008;17:754-5.

9. Akagi S, Shimada H, Kato I, Saito T, Ogawa R. Cervical spondylitis and epidural abscess caused by Salmonella enteritidis with tetraplegia. Orthopedics 1998;21:1289-91.

10. Choi YS, Cho WJ, Yun SH, et al. A case of back pain caused by Salmonella spondylitis. A case report. Korean J Anesthesiol 2010;59 Suppl:S233-7.

11. Schuler A, Schaumann D, Manns MP, Koch KM. Lumbar spondylodiscitis caused by Salmonella enteritidis. Dtsch Med Wochenschr 1994;119:1383-7.

12. Acosta FL Jr, Chin CT, Quinones-Hinojosa A, Ames CP, Weinstein PR, Chou D. Diagnosis and management of adult pyogenic osteomyelitis of the cervical spine. Neurosurg Focus 2004;17:E2.

13. Kim CJ, Song KH, Jeon JH, et al. A comparative study of pyogenic and tuberculous spondylodiscitis. Spine (Phila Pa 1976) 2010;35:E1096-100.

14. Harada Y, Tokuda O, Matsunaga N. Magnetic resonance imaging characteristics of tuberculous spondylitis vs. pyogenic spondylitis. Clin Imaging 2008;32:303-9.

15. Cheung WY, Luk KD. Pyogenic spondylitis. Int Orthop 2012;36:397-404.

16. Linhardt O, Matussek J, Refior HJ, Krodel A. Longterm results of ventro-dorsal versus ventral instrumentation fusion in the treatment of spondylitis. Int Orthop 2007;31:113-9.

17. Lee MC, Wang MY, Fessler RG, Liauw J, Kim DH. Instrumentation in patients with spinal infection. Neurosurg Focus 2004;17:E7.

18. Korovessis P, Petsinis G, Koureas G, Iliopoulos P, Zacharatos S. One-stage combined surgery with mesh cages for treatment of septic spondylitis. Clin Orthop Relat Res 2006;444:51-9.

19. Nakase H, Matsuda R, Tamaki R, Tei R, Park YS, Sakaki T. Two-stage management for vertebral osteomyelitis and epidural abscess: technical note. Neurosurgery 2006;58:E1219. 